\title{
Are Wildfires a Threat to Fungi in European Pinus Forests? A Case Study of Boreal and Mediterranean Forests
}

\author{
Iván Franco-Manchón ${ }^{1}$, Kauko Salo ${ }^{2}$, Juan Andrés Oria-de-Rueda ${ }^{1}$, José Antonio Bonet ${ }^{3,4}{ }^{\mathbb{C}}$ \\ and Pablo Martín-Pinto ${ }^{1, *}$ \\ 1 Sustainable Forest Management Research Institute, University of Valladolid (Palencia), Avda. Madrid 44, \\ 34071 Palencia, Spain; ivan.franco@alumnos.uva.es (I.F.-M.); oria@agro.uva.es (J.A.O.-d.-R.) \\ 2 Natural Resources Institute Finland (Luke), Yliopistokatu 6, FI-80100 Joensuu, Finland; kauko.salo@luke.fi \\ 3 Department of Crop and Forest Sciences-Agrotecnio Center, Universitat de Lleida (UdL-Agrotecnio), \\ Avda. Rovira Roure, 191, E-25198 Lleida, Spain; jantonio.bonet@pvcf.udl.cat \\ 4 Centre de Ciència i Tecnologia Forestal de Catalunya (CTFC), Ctra. de St. Llorenç de Morunys km 2, \\ E-25280 Solsona, Spain \\ * Correspondence: pmpinto@pvs.uva.es; Tel.: +34-979-108-340; Fax: +34-979-108-440
}

Received: 12 February 2019; Accepted: 2 April 2019; Published: 4 April 2019

\begin{abstract}
Natural forests and plantations of Pinus are ecologically and economically important worldwide, producing an array of goods and services, including the provision of non-wood forest products. Pinus species play an important role in Mediterranean and boreal forests. Although Pinus species seem to show an ecological adaptation to recurrent wildfires, a new era of mega fires is predicted, owing to climate changes associated with global warming. As a consequence, fungal communities, which are key players in forest ecosystems, could be strongly affected by these wildfires. The aim of this study was to observe the fungal community dynamics, and particularly the edible fungi, in maritime (Pinus pinaster Ait.), austrian pine (Pinus nigra J.F. Arnold), and scots pine (Pinus sylvestris L.) forests growing under wet Mediterranean, dry Mediterranean, and boreal climatic conditions, respectively, by comparing the mushrooms produced in severely burned Pinus forests in each area. Sporocarps were collected during the main sampling campaigns in non-burned plots, and in burned plots one year and five years after fire. A total of 182 taxa, belonging to 81 genera, were collected from the sampled plots, indicating a high level of fungal diversity in these pine forests, independent of the climatic conditions. The composition of the fungal communities was strongly affected by wildfire. Mycorrhizal taxa were impacted more severely by wildfire than the saprotrophic taxa, particularly in boreal forests-no mycorrhizal taxa were observed in the year following fire in boreal forests. Based on our observations, it seems that fungal communities of boreal P. sylvestris forests are not as adapted to high-intensity fires as the Mediterranean fungal communities of $P$. nigra and P. pinaster forests. This will have an impact on reducing fungal diversity and potential incomes in rural economically depressed areas that depend on income from foraged edible fungi, one of the most important non-wood forest products.
\end{abstract}

Keywords: fungal diversity; fire disturbance; edible mushrooms; rural incomes

\section{Introduction}

Natural forests and plantations of Pinus have historically played important economic and ecological roles throughout Europe [1,2]. They have traditionally provided raw materials [3] and acted as regulators in water flow systems [4]. Recently, their role as ecosystem service suppliers has been highlighted [5]. Pine forests are considered to be important carbon sinks [6], with fungal communities 
playing a key role [7]. For example, saprotrophic fungi in these fungal communities are involved in soil formation and soil fertility by decomposing plant and animal remains, recycling nutrients, and translocating carbon, nitrogen, phosphorous, and other elements from dead plant material to the soil organic horizon [8]. By contrast, mycorrhizal fungi establish symbiotic relationships with plants, helping them to absorb or synthesize substances that the plants cannot take up through their roots, or improving their survival after disturbances, such as wildfires [9]. Mycorrhizal fungi are also biodiversity regulators: for example, some taxa secrete allelopathic compounds to inhibit the growth of certain plant species [10]. One example is Glomus macrocarpum, an AMF (Arbuscular Micorrhizal Fungi) which helps some plants to generate root biomasss [11]. In addition to the ecological role of fungal communities in forest ecosystems, edible mushrooms associated with these systems can also be important in terms of rural development and the generation of incomes in rural areas, being considered one of the most relevant non-wood forest products [12]. It is worth noting that nowadays, not only do the sporocarps have an economic value, but also recreational mushrooms collectors might gain an income through the myco-tourism activity [13].

Historically, forest systems dominated by Pinus species have been affected by wildfires, regardless of the Pinus species or the latitude in which they are located $[14,15]$. In general terms, in Europe, the resilience of Pinus forests to fire is highly determined by the Pinus species [16]. For example, although Pinus sylvestris seems to be adapted to low-intensity fires in boreal forests [17], in central areas of Europe, P. sylvestris forests seem to be less adapted to fires than Pinus nigra forests [18]. Furthermore, a previous study demonstrated that $P$. nigra forests in the southern latitudes of Europe are less pyrophytic than P. pinaster, demonstrating a latitudinal gradient in fire sensitivity [19].

Fungal communities are strongly affected by fire, depending on fire intensity, which reflects changes to the soils physical, chemical, and biochemical properties [20]. Furthermore, vegetation cover losses and changes in plant composition are intimately related to the fungal communities living in a symbiotic/saprophytic relation with them. The severity of effects caused by fire in the ecosystem, and hence its affect on fungal communities, also depends on other factors, such as the fuel load [21], soil moisture [22], temperature, and time lapsed from the last rainfall [23], and other environmental weather conditions during the fire event.

After a fire event, the succession of fungal communities is determined by the plant communities that evolve after the fire [24]. The post-fire fungal fruiting linked to vegetation restoration has also been observed in P. pinaster and P. nigra forests in Mediterranean areas $[25,26]$. These authors found that the restoration of mycorrhizal taxa after fire was linked to the recovery of the host species, which were affected by wildfire. The immediate fire effect is the strong modification of the pre-fire fungal communities, which implies changes in the genera and mycorrhizal/saprotrophic ratio [26,27]. This is followed by a secondary succession, which begins with the occurrence of the first significant rain [28]. Usually, there are pyrophytic or pioneer fungal taxa fruiting bodies just after a fire, which usually develop from the spore bank present in the pre-fire soil [28]. However, many saprotrophic species live in humus, litter and plant debris, needles, dung, other macrofungi, burnt humus. or charred wood in boreal forests [29]. These species are favored by the new ecological conditions that occur after a fire. After this first step, under Mediterranean conditions, post-fire fungi are mostly replaced by late-stage species, such as Tricholoma equestre or Suillus bellini [25]. Fungal succession after a fire has also been reported in the northern latitudes of Europe in a P. sylvestris forest-three years after a fire, pyrophytic fungal species were replaced by pre-fire species [30].

A new era of mega fires is predicted owing to climate changes associated with global warming [31]. Knowledge about fungal communities in pine forests and their response to high-severity fires is needed because there is a serious risk that some fungal species, including targeted non-wood forest products that are not adapted to this threat, may disappear. Thus, we hypothesize that fungal community adaptations to host, climate conditions, and fire occurrence will translate into differences in fungal composition and recovery following fire in Northern and Southern Europe. Therefore, the aim of the study was to understand the different fungal carpophores patterns, following high-severity wildfires in 
P. pinaster, P. nigra, and P. sylvestris forests growing under wet Mediterranean, dry Mediterranean, and boreal climatic conditions, respectively, with special emphasis on economically valuable mushrooms. Our specific objectives in the three pine forests were to: (1) compare the fungal communities present in the non-burned Pinus forests; (2) observe the immediate effect of fire on the fungal communities associated with pine ecosystems; and (3) observe the short-term fungal dynamics after fire disturbance.

\section{Materials and Methods}

\subsection{Study Site}

This observational study was conducted in three geographical areas dominated by Pinus pinaster Ait., Pinus nigra J.F. Arnold, and Pinus sylvestris L. located within wet Mediterranean, dry Mediterranean, and boreal ecosystems, respectively [26,27,32]. All study sites were affected by high-severity wildfires, where their canopy and understory were burned, and the soil organic layer was consumed [33]. A large high-severity wildfire occurred in August 2002 that burnt 1427 ha of wet Mediterranean pine forest. At that time, the forest was dominated by 50 -year-old P. pinaster plantations that had been established by the Spanish Forest Services in previously deforested areas. The dry Mediterranean forest was dominated by a 50-year-old Pinus nigra plantation, which had been planted with the aim of restoring an afforested area. The wildfire took place in 2002 (118.03 ha burned). Finally, we studied a natural boreal forest of P. sylvestris that was affected by a 143 ha wildfire in June 1992. The dominant pines in the forest at this time were 81-126 years old. The location of the forest areas, as well as the climate and soil characteristics, are shown in Table 1.

Table 1. Location, climate, soil, and shrub vegetation characteristics of the studied sites.

\begin{tabular}{|c|c|c|c|}
\hline Characteristics & Pinus pinaster & Pinus nigra & Pinus sylvestris \\
\hline Location & $\begin{array}{c}\text { Northwestern Spain (0706439 } \\
\text { Longitude-UTM, } 4632901 \\
\text { Latitude-UTM) }\end{array}$ & $\begin{array}{c}\text { Northcentral Spain (376090 } \\
\text { Longitude-UTM, } 4711724 \\
\text { Latitude-UTM) }\end{array}$ & $\begin{array}{l}\text { Eastern Finland (304500 } \\
\text { Longitude-UTM, } \\
\text { 631600-Latitude-UTM) }\end{array}$ \\
\hline Altitude & 750-780 m.a.s.l. & 950-960 m.a.s.l & 180 m.a.s.l. \\
\hline Mean annual rainfall (mm) & $744.0 \mathrm{~mm}$ & $528.1 \mathrm{~mm}$ & $601.0 \mathrm{~mm}$ \\
\hline $\begin{array}{l}\text { Variation of the precipitation of } \\
\text { the sampling years with respect } \\
\text { to the mean rainfall }(\%)\end{array}$ & $\begin{array}{l}\text { NB: }+19 \\
\text { B1: }+19 \\
\text { B5: }+37\end{array}$ & $\begin{array}{l}\text { NB: }-18 \\
\text { B1: }-18 \\
\text { B5: }-18\end{array}$ & $\begin{array}{l}\text { NB: }-12 \\
\text { B1: }-12 \\
\text { B5: }-15\end{array}$ \\
\hline Mean $\mathrm{T}^{\mathrm{a}}\left({ }^{\circ} \mathrm{C}\right)$ & $14.5^{\circ} \mathrm{C}$ & $10.5^{\circ} \mathrm{C}$ & $2.1^{\circ} \mathrm{C}$ \\
\hline $\begin{array}{l}\text { Variation of the temperature of } \\
\text { the sampling years with respect } \\
\text { to the mean temperature }(\%)\end{array}$ & $\begin{array}{l}\text { NB: }+18 \\
\text { B1: }+18 \\
\text { B5: }+18\end{array}$ & $\begin{array}{l}\text { NB: }+18 \\
\text { B1: }+18 \\
\text { B5: }+18\end{array}$ & $\begin{array}{l}\text { NB: }-20 \\
\text { B1: }-20 \\
\text { B5: } 0\end{array}$ \\
\hline Soil characteristics & $\begin{array}{c}\text { Paleozoic metamorphic rocks, } \\
\text { dominated by Ordovician and } \\
\text { Silurian shales }\end{array}$ & $\begin{array}{l}\text { Cluster, siliceous sand and } \\
\text { shales }\end{array}$ & $\begin{array}{c}\text { Nutrient-poor mineral soil, i.e., } \\
\text { podzol soil, acidic and } \\
\text { oligotrophic }\end{array}$ \\
\hline $\begin{array}{l}\text { Shrub and secondary species } \\
\text { communities }\end{array}$ & $\begin{array}{l}\text { Quercus ilex subsp. ballota } \\
\text { (Desf.) Samp., Q. pyrenaica } \\
\text { Willd and Cistus ladanifer L. }\end{array}$ & $\begin{array}{l}\text { Q. pyrenaica Willd and C. } \\
\text { laurifolius L. }\end{array}$ & $\begin{array}{l}\text { Picea abies (L.) H. Karst, } \\
\text { Vaccinium myrtillus L., V. } \\
\text { vitis-idaea L., Betula pendula } \\
\text { Roth and B. pubescens Ehrh. }\end{array}$ \\
\hline
\end{tabular}

UTM: Universal Transverse Mercator coordinate system. NB: non-burned; B1: one year after fire; B5: five years after fire.

\subsection{Sampling Design}

For each study site (wet Mediterranean, dry Mediterranean, and boreal) we selected three stand types based on their fire interval: non-burned (NB), and burned one year (1B) and five years after fire (5B). Burned and non-burned stands were about $1 \mathrm{~km}$ apart from each other in the same forest. Non-burned stands were not affected by fire, at least in the last 40 years. The fungal diversity of the stands was obtained by sampling three $100 \mathrm{~m}^{2}$ plots per stand. Within each of the selected stands, plots were placed systematically about $120 \mathrm{~m}$ apart from each other. All plots were similar in terms of their ecological conditions, such as climate, altitude, and soil, aiming to minimize the differences between forest stands for each geographical area. 
Sporocarps were collected weekly during the main sampling campaigns. In the cases of wet Mediterranean and dry Mediterranean, the sporocarps were sampled from October to December, and in the boreal stands from the beginning of August to the end of October, this coincided with the period of maximum mushroom emergence. Thus, the number of individual samplings was the same in all the study sites.

\subsection{Taxa Identification and Classification}

The collected sporocarps were identified down to species level whenever possible. The sporocarps that could only be identified to genus level were included as genus taxa $[34,35]$. Some checking was done with Latin names according to a previous study [36]. The Index Fungorum database (www. indexfungorum.org) was used to obtain the current name and author for each taxon. The edibility classification of each taxon was determined according to a previous study [34] in Spain and [37] in Finland.

\subsection{Statistical Analysis}

The Jaccard similarity matrix was used to compare the fungal genera in the three study areas in order to determine differences in fungal community composition. In order to analyze differences in fungal species composition in different regions and at different successional stages, we performed a detrended correspondence analysis (DCA) [38] using the software CANOCO for Windows version 4.5 [39], with abundance data as the response variable.

\section{Results}

\subsection{Descriptive Statistics}

A total of 182 taxa belonging to 83 genera were collected from the sampled plots during the sampling years (Table S1 and Figure 1). Of the total identified taxa, $78(43 \%)$ of the taxa were classified as mycorrhizal and $104(57 \%)$ were classified as saprotrophic. $54(30 \%)$ of the total taxa were classified as edible mushrooms.

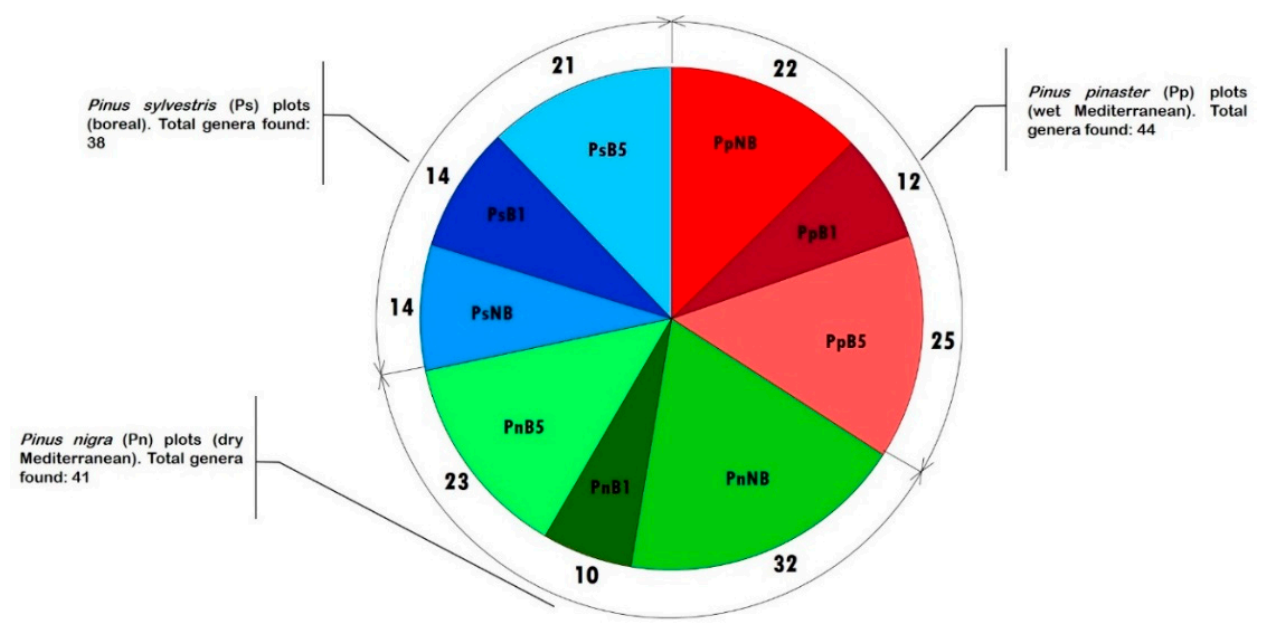

Figure 1. Number of genera per studied area in different years of the experiment. In red are P. pinaster plots, in green are P. nigra plots, and in yellow are P. sylvestris plots. NB: non-burned; B1: one year after fire; B5: five years after fire. 
In the wet Mediterranean 50-year-old P. pinaster plots, 62 taxa were collected in total during the two sampling years and $48 \%$ of them formed mycorrhizal associations. In terms of edibility, in P. pinaster plots, 32 (52\%) were classified as saprotrophic taxa. In total, $23(37 \%)$ taxa were classified as edible fungi.

In the dry Mediterranean P. nigra ecosystem, 91 taxa were collected over the sampling period. Forty-four (48\%) of the taxa were classified as mycorrhizal and 47 (52\%) were classified as saprotrophic fungi. Forty-two (46\%) of the total collected taxa were classified as edible fungi, including Tricholoma terreum and Macrolepiota procera, which are sold commercially in markets in the area.

Sporocarps collected from boreal P. sylvestris plots were classified into 60 taxa, of which $18(30 \%)$ were mycorrhizal and $42(69 \%)$ were saprotrophic. Five (8\%) of the total collected taxa were classified as edible fungi: Lactarius mammosus, Russula paludosa, R. decolorans, Suillus variegatus, and Gyromitra esculenta, which are all sold commercially, except for L. mammosus. The list also includes Gyromitra esculenta, which is a deadly poison when consumed fresh [36].

Some similarities were observed when comparing the fungal genera associated with the three hosts. The P. pinaster and P. nigra ecosystems were similar to each other, hosting 39 common fungal genera (Table 2). We found 15 and 14 common genres when comparing P. sylvestris with P. pinaster and with $P$. nigra plots, respectively (Table 2). Some fungal genera were exclusively collected in these ecosystems, such as Inocybe sp., Tremella sp., and Clitocybe sp. Similarly, Galerina sp. was exclusively hosted by P. nigra and P. sylvestris forests. Some other taxa, such as Mycena sp., Laccaria sp., and Cortinarius sp., were found in all three ecosystems.

Table 2. Jaccard similarity coefficients (lightface) and the number of genera in common (boldface) among the three different study sites.

\begin{tabular}{cccc}
\hline Study Sites & $\begin{array}{c}\text { Wet Mediterranean } \\
\text { Pinus pinaster }\end{array}$ & $\begin{array}{c}\text { Dry Mediterranean } \\
\text { Pinus nigra }\end{array}$ & $\begin{array}{c}\text { Boreal } \\
\text { Pinus sylvestris }\end{array}$ \\
\hline Wet Mediterranean Pinus pinaster & & 0.886 & 0.231 \\
Dry Mediterranean Pinus nigra & 39 & 14 & 0.215 \\
Boreal Pinus sylvestris & 15 & & \\
\hline
\end{tabular}

\subsection{Fungal Richness Succession after Fire}

In all study sites, more than half of the species were decreased one year after fire. However, the number of taxa collected five years after fire were more similar to the non-burned plots (Table S1). The highest number of taxa (59) was found in non-burned P. nigra plots in the dry Mediterranean ecosystem (Table S1). The number of taxa present one year after fire was lower in all ecosystems. Mycorrhizal taxa were not found one year after fire in the studied boreal pine forest.

One year after fire, in all three sites, the number of saprotrophic taxa observed tended to be higher than the number of mycorrhizal taxa. Mycorrhizal recovery rates were slow in boreal forests, with only $25 \%$ of the mycorrhizal taxa that were present in the non-burned plots observed in the burned plots five years after wildfire.

The Jaccard similarity coefficients linked to succession following fire indicated that $P$. pinaster and P. nigra, which hosted 13 and 12 common genera under NB and B5 conditions, respectively, showed the greatest interhost similarity. The $P$. sylvestris plots were more similar to that of $P$. nigra than $P$. pinaster, with a greater number of genera common to both ecosystems in every comparison. In $P$. nigra and $P$. pinaster forests, 16 and 11 common genera appeared in both the NB and the B5 plots, respectively, indicating that genera recovered more rapidly in these plots compared with the P. sylvestris plots (Table 3). 
Table 3. Jaccard similarity coefficients (lightface) and the number of genera in common (boldface) among the three different study sites at different periods after fire.

\begin{tabular}{cccccccccc}
\hline Study Sites & PpNB & PpB1 & PpB5 & PnNB & PnB1 & PnB5 & PsNB & PsB1 & PsB5 \\
\hline PpNB & & 0.172 & 0.306 & 0.317 & 0.067 & 0.250 & 0.161 & 0.029 & 0.103 \\
PpB1 & 5 & & 0.194 & 0.100 & 0.100 & 0.129 & 0.040 & 0.182 & 0.138 \\
PpB5 & 11 & 6 & & 0.239 & 0.207 & 0.333 & 0.147 & 0.114 & 0.150 \\
PnNB & 13 & 4 & 11 & & 0.235 & 0.410 & 0.211 & 0.045 & 0.152 \\
PnB1 & 2 & 2 & 6 & 8 & & 0.179 & 0.143 & 0.091 & 0.148 \\
PnB5 & 9 & 4 & 12 & 16 & 5 & & 0.057 & 0.028 & 0.048 \\
PsNB & 5 & 1 & 5 & 8 & 3 & 2 & & 0.120 & 0.167 \\
PsB1 & 1 & 4 & 4 & 2 & 2 & 1 & 3 & & 0.207 \\
PsB5 & 4 & 4 & 6 & 7 & 4 & 2 & 5 & 6 &
\end{tabular}

Pp: Pinus pinaster forests growing under wet Mediterranean conditions; Pn: Pinus nigra forests growing under dry Mediterranean conditions; Ps: Pinus sylvestris forests growing under boreal conditions. NB: non-burned; B1: one year after fire; B5: five years after fire.

\subsection{Taxa Composition}

Two clear trends were found to be linked to the DCA horizontal axis (Figure 2). Axis 1 separates taxa associated with Mediterranean plots from the taxa associated with boreal plots. Also, axis 2 separates Mediterranean plots from each other. P. sylvestris and P. pinaster forests have similar patterns, in that the NB communities differ from $1 \mathrm{~B}$ and $5 \mathrm{~B}$, but this is not visible for P. nigra.

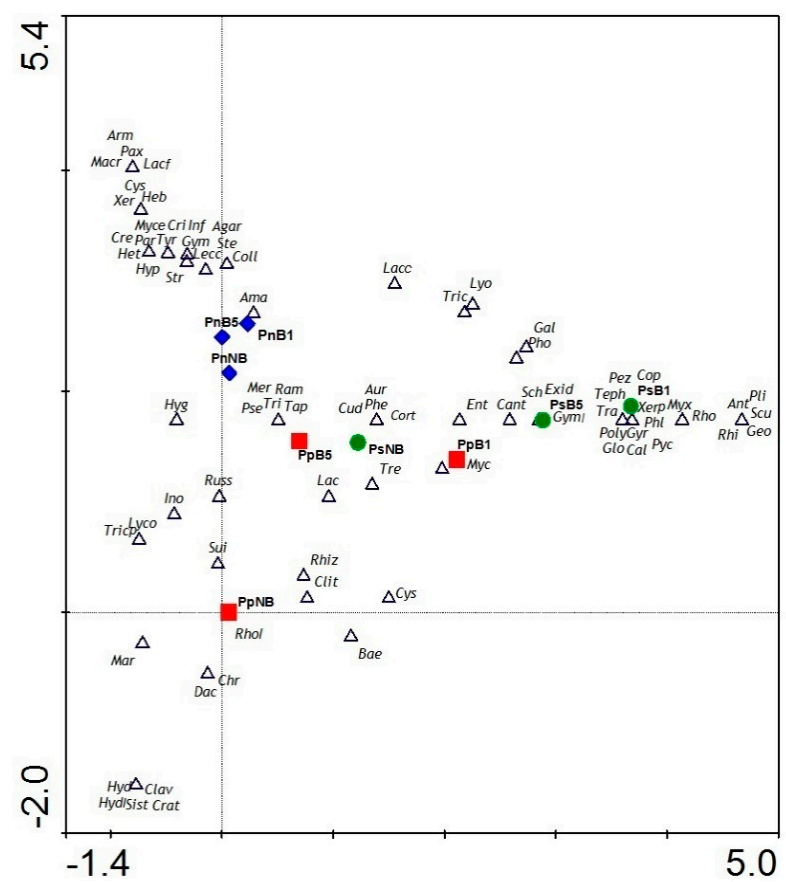

Figure 2. Detrended correspondence analysis for the three different study sites. Pp (red square): Pinus pinaster forests growing under wet Mediterranean conditions; Pn (blue diamond): Pinus nigra forests growing under dry Mediterranean conditions; Ps (green circle): Pinus sylvestris forests growing under boreal conditions. NB: non-burned; B1: one year after fire; B5: five years after fire. Taxa are marked using the codes shown in Table S1.

Pholiota highlandensis and Laccaria laccata, considered as pyrophytic taxa and early successional taxa, were associated with the burned stands at all sites. L. laccata, a mycorrhizal macrofungi, was the first post-fire pioneer taxa observed after the forest fire at the boreal study sites. The agaric Lyophyllum anthracophilum and the ascomycetes Plicaria endocarpoides and Peziza echinospora were found at B1 sites but were not observed at the B5 sites or in wet Mediterranean and dry Mediterranean Pinus study sites. Furthermore, some species of the genus Rhizopogon, which are frequently associated with fire, were observed only in the P. nigra and P. pinaster burned plots. 
Multistage taxa were found in the three ecosystems, such as Tremella mesenterica in P. pinaster forests, Stereum hirsutum in P. nigra forests, and Gymnopilus penetrans in P. sylvestris forests.

Some mycorrhizal taxa, namely Hygrophorus chrysodon, Lyophyllum decastes, Leccinellum corsicum, and Lactarius tesquorum, were associated with a Mediterranean climate and were only observed 5-years-after-fire in P. nigra and P. pinaster plots. Lactarius mammosus was the only edible mycorrhizal species found 5 years after fire in P. sylvestris plots in boreal forests.

A comparison of the edible species observed also revealed a negative effect of fire in all the forests ecosystems. The most appreciated and demanded fungal species, such as Lactarius deliciosus, Suillus luteus, Suillus granulatus, and Tricholoma portentosum in Mediterranean forests, and Russula decolorans, Russula paludosa, and Suillus variegatus in boreal forests, were not observed 1 and 5 years after fire.

\section{Discussion}

\subsection{General Data}

In this study, we observed a greater level of mushroom diversity in the different conifer Pinus forests under wet Mediterranean, dry Mediterranean, and boreal conditions in Northern and Southern Europe than was reported in previous studies of forests comprising several species of Pinus [40,41]. For example, in a one-year mycological survey in P. pinaster, P. sylvestris, P. nigra, and P. halepensis forests [40], the authors found 84 different taxa in three $100 \mathrm{~m}^{2}$ plots in each area, whereas in our study we observed a total of 182 taxa. The high level of fungal richness observed in this study could be due to the presence of stands with different age stages [40], added to the emergence of taxa linked to young stands and wildfires [42], demonstrating the rapid dynamic nature of fungal communities. Our study also highlights the relevance of pine forest ecosystems as a source of edible fungi. These Non-Wood Forests Products are especially significant in dry Mediterranean Forests, where $46 \%$ of the identified taxa are considered as suitable for human consumption.

The proportions of mycorrhizal and saprotrophic fungi observed in the forests were strongly affected by the fire in the boreal pine forest, with no mycorrhizal taxa observed one year after the fire and only a few observed in plots 5 years after the fire. A negative effect of fire on the relative presence of the mycorrhizal taxa group has been previously reported [43]. The authors observed that a decline in the biomass in burned boreal forests was associated with an increase in the relative abundance of saprophytic fungi. The reduced presence of mycorrhizal fungi in the following years after a fire disturbance provides an opportunity for living saprophytic fungi to become more abundant [43]. After fire there is a lot of dead plant material, which can be available for the saprotrophic species. In contrast, the absence of host plants induces the mycorrhizal taxa to reduce their presence or even disappear.

Some similarities were observed when comparing the number of genera associated with the three hosts. P. pinaster and P. nigra were more closely associated with each other than with P. sylvestris, hosting 39 common fungal genera, whereas only 15 and 14 of the genera found in our P. sylvestris forest were also found in P. pinaster and P. nigra sites, respectively. Here, we have previously observed that soil, temperature, and evapotranspiration are decisive factors that influence fungal compositions when comparing them with forest type and vegetation composition [40,44]. Previous studies found a greater number of common fungal taxa associated with Quercus pyrenaica and P. sylvestris and P. pinaster than were found between Quercus species [40].

\subsection{Effect of Fire on Richness and Succession after Fire}

All the forests in this study were strongly affected by high-intensity fire. The year after the fire, there was a decrease in the number of fungal taxa, mainly mycorrhizal taxa. The negative impact of high-severity wildfire on the fungal richness has been shown in previous studies carried out in wet Mediterranean, dry Mediterranean forests [25,26,35], and boreal pine forests [32,43,45]. 
The total absence of mycorrhizal fruiting bodies in boreal $P$. sylvestris forests just after a fire reflects a low level of adaptation of this ecosystem to high-severity fires. Such results are also a consequence of the cold climate and acidic nature of the boreal soils, implying that the soil processes are slower [46] than in Mediterranean forests, which in practice may represent a slow recovery after the disturbance. In wet Mediterranean and dry Mediterranean ecosystems, the consequences for mycorrhizal taxa were not dramatic. In both cases, by five years after fire, the number of taxa had increased, showing an adaptation to fire, as shown in previous studies $[47,48]$. Furthermore, the number of mycorrhizal taxa collected one year after fire in the P. pinaster plots was similar to the average number of taxa reported in other burned P. pinaster stands [49].

The rapid recovery in the Mediterranean forests is frequently favoured by secondary pioneer vegetation. This fire-adapted vegetation, mainly shrubs, colonizes the area very quickly after one fire event and some multi-host fungal taxa use this fire-prone Mediterranean vegetation as a bridge, while new pine seedlings naturally grow [35]. Pholiota highlandensis and Myxomphalia maura were the first pioneer species to colonize the boreal forests one-year-after fire (B1). These species do not require vegetation to colonize a burned plot because they are carbophilous species living on charred wood.

Fungal taxa have developed resistance structures, such as infected root tips, sclerotia, or resistant spores [24], to survive after disturbances, such as forest fires. The ectomycorrhizal fungal community that is established after a fire is a reflection of the soil resistance structure bank that existed before the disturbance [50]. A rapid increase in the number of mycorrhizal taxa after a fire could be due to the high photosynthetic activity observed in young plants after fire in the Mediterranean region [51]. In addition, more nutrients are available after a fire, which could enhance the fruiting of mycorrhizal fungal species associated with their roots, such as Boletus edulis or Lactarius deliciosus, the most important non-wood forest products in the area [52]. The activity of these fungi also depends on the nutrients released from soil organic matter, which will depend on the increment in minerals due to fire [53,54]. Some studies have shown that some mycorrhizal pyrophytic taxa, such as Lactarius quietus, showed an enzymatic plasticity when subjected to a fire disturbance [55]. However, more than a decade may be required to re-establish primary productivity in boreal forests after high-severity wildfires [56]. Thus, post-fire effects that influence the amount of soil carbon and organic matter in those forests may similarly persist a decade after the disturbance [46].

A different trend was observed for saprotrophic fungi. This functional fungal group recovered its pre-disturbance state earlier than the mycorrhizal taxa. Saprotophs are pioneer species compared to mycorrhizal fungi, which grow faster when the conditions after fire are favourable for them. Also, the litter pulse after fire is very beneficial for saprotophs, due in part to the availability of higher amount of organic material. The recovery for mycorrhizal fungi can be slower, especially if their host trees are killed in the fire.

\subsection{Taxa Composition}

The effect of fire on fungal composition indicates that identified taxa in non-burned sites are more similar to the taxa collected 5 years after fire than those collected 1 year after fire. This suggests that the burned sites may recover their pre-fire fungal composition within a few years after the disturbance. This was previously reported in P. nigra forests, where a quick recovery of fungal communities was observed just 5 years after fire [26]. In wet Mediterranean plots, the immediate effect of fire and the rapid recovery of species richness have also been studied [25]. However, the taxa composition five years after fire was still different to that of non-burned stands [51]. This has previously been reported for mycorrhizal populations in wet Mediterranean pine forests, which not only showed an increase in the number of species between the early and late stages of succession but also a shift in composition across the chronosequence [25].

Geopyxis carbonaria, Rhizina undulata, Myxomphalia maura, Pholiota highlandensis, and Peziza echinospora, which are on the right-hand side of axis 1 in the DCA, were associated with the burned stands in boreal forests. Some studies previously reported that Pholiota highlandensis and Peziza spp. were associated 
with post-fire conditions $[28,35,57]$. We also found some species of the genus Rhizopogon, which were only present in $P$. nigra and P. pinaster burned plots, which agrees with previous studies in the wet Mediterranean area, which reported that this genus was associated with wildfires [42]. The adaptation of this genus to fire is due to their rhizomorphs and mycelial fans, which can extend considerable distances from the tree root, and hence have a greater chance of surviving a fire [58].

Laccaria laccata, Mycena spp. and Gymnopilus spp. were collected in the burned plots of the three Pinus forests. Although these taxa can be considered as pioneer fungi after fire [59], they can also fruit some years after the disturbance, unlike Pholiota highlandensis and Peziza spp., which only fruit in the period just following a fire. Multistage taxa Tremella mesenterica and Stereum hirsutum were found in all the P. pinaster and P. nigra stands, respectively, whereas Gymnopilus penetrans was collected in burned and non-burned stands of $P$. sylvestris. These taxa are considered decomposers and not only play a key role in wet Mediterranean forest soils, where low organic matter ratios are observed, but also in boreal forest soils, where low temperatures reduce the opportunities for wood decomposition. Lactarius tesquorum and Leccinellum corsicum were found in ecosystems under the influence of a Mediterranean climate, where recurrent wildfires take place [60]. This study represents, to our knowledge, a first attempt to understand the effect of high severity fires on mushrooms communities in Pinus forests ecosystems under different geographical areas in Europe. As an observational study, these findings must be seen as preliminary, due to the inherent limitations of this type of study. Owing to the importance of fungi in ecosystem dynamics, further studies are needed to design conservation strategies that account for the high risk of fungal diversity losses.

\section{Conclusions}

Our results showed that a high level of fungal diversity exists in our different Pinus study sites, under wet Mediterranean, dry Mediterranean, and boreal conditions in Northern and Southern Europe. P. nigra plots hosted the highest level of taxa richness, possibly because the dry Mediterranean plots have adapted the most to the occurrence of high-intensity fires. Fungal communities in the boreal forest were the most affected by fire, with no mycorrhizal fruiting bodies observed one year after forest fire. In addition, we observed that some taxa were favoured in the short term by fire, and that the number of species not only increased from the early to late stages of colonization but also shifted in composition across the chronosequence. In the present context of global warming, in which high-severity fires are already playing a stronger role in ecosystem functioning, ecological adaptation to fire will be crucial for the survival of fungal diversity and for its ecological and economic consequences. Among them we would highlight a reduction in ecological biodiversity and a decrease in income from Non Timber Forest Products, which could be significant in rural, economically-depressed areas.

Supplementary Materials: The following are available online at http:/ /www.mdpi.com/1999-4907/10/4/309/s1. Table S1: Total fungal taxa collected from Wet Mediterranean Pinus pinaster, Dry Mediterranean Pinus nigra, and Boreal Pinus sylvestris forests.

Author Contributions: Conceptualization, P.M.-P. and J.A.B.; methodology, K.S. and P.M.-P.; software, I.F.-M.; taxonomical identification resources, J.A.O.-d.R., and K.S.; writing-original draft preparation, I.F.-M.; writing-review and editing, P.M.-P.o and J.A.B.

Funding: This research was funded by FPS COST Action FP1203 “European non-wood forest products network (NWFPs)". This work was partially supported by two Research Projects funded by Junta de Castilla y León (Ref.: VA018B05 and VA050P17) and co-funded by the Spanish Ministry of Education and Culture under Salvador de Madariaga grant agreement number PRX17/00315 and by the Spanish Ministry of Economy and Competitivity (MINECO) (grant number AGL2015-66001-C3). José Antonio Bonet benefited from a Serra-Húnter Fellowship provided by the Generalitat of Catalunya.

Acknowledgments: This work was made possible with the help of Metsähallitus (Parks \& Wildfire Finland), which provided permits for field work during sampling years in Jäkäläkangas.

Conflicts of Interest: The authors declare no conflict of interest. 


\section{References}

1. Espelta, J.M.; Retana, J.; Habrouk, A. An Economic and Ecological Multi-Criteria Evaluation of Reforestation Methods to Recover Burned Pinus Nigra Forests in NE Spain. For. Ecol. Manag. 2003, 180, 185-198. [CrossRef]

2. Hanewinkel, M.; Cullmann, D.A.; Schelhaas, M.; Nabuurs, G.; Zimmermann, N.E. Climate Change May Cause Severe Loss in the Economic Value of European Forest Land. Nat. Clim. Chang. 2012, 3, $203-207$. [CrossRef]

3. Miura, S.; Amacher, M.; Hofer, T.; San-Miguel-Ayanz, J.; Ernawati; Thackway, R. Protective Functions and Ecosystem Services of Global Forests in the Past Quarter-Century. For. Ecol. Manag. 2015, 352, 35-46. [CrossRef]

4. Ramos-Diez, I.; Navarro-Hevia, J.; San Martín Fernández, R.; Díaz-Gutiérrez, V.; Mongil-Manso, J. Analysis of Methods to Determine the Sediment Retained by Check Dams and to Estimate Erosion Rates in Badlands. Environ. Monit. Assess. 2016, 188, 405. [CrossRef] [PubMed]

5. Roces-Díaz, J.V.; Vayreda, J.; Banqué-Casanovas, M.; Díaz-Varela, E.; Bonet, J.A.; Brotons, L.; de-Miguel, S.; Herrando, S.; Martínez-Vilalta, J. The Spatial Level of Analysis Affects the Patterns of Forest Ecosystem Services Supply and Their Relationships. Sci. Total Environ. 2018, 626, 1270-1283. [CrossRef] [PubMed]

6. Pardos, M.; Pérez, S.; Calama, R.; Alonso, R.; Lexer, M.J. Ecosystem Service Provision, Management Systems and Climate Change in Valsaín Forest, Central Spain. Reg. Environ. Chang. 2017, 17, 17-32. [CrossRef]

7. Clemmensen, K.E.; Bahr, A.; Ovaskainen, O.; Dahlberg, A.; Ekblad, A.; Wallander, H.; Stenlid, J.; Finlay, R.D.; Wardle, D.A.; Lindahl, B.D. Roots and Associated Fungi Drive Long-Term Carbon Sequestration in Boreal Forest. Science 2013, 339, 819-824. [CrossRef]

8. Watkinson, S.; Bebber, D.; Darrah, P.; Fricker, M.; Boddy, L. The Role of Wood Decay Fungi in the Carbon and Nitrogen Dynamics of the Forest Floor; Gadd, G.M., Ed.; Cambridge University Press: Cambridge, UK, 2006.

9. Garcia, C.; Hernandez, T.; Roldan, A.; Albaladejo, J.; Castillo, V. Organic Amendment and Mycorrhizal Inoculation as a Practice in Afforestation of Soils with Pinus Halepensis Miller: Effect on Their Microbial Activity. Soil Biol. Biochem. 2000, 32, 1173-1181. [CrossRef]

10. Hättenschwiler, S.; Tiunov, A.V.; Scheu, S. Biodiversity and Litter Decomposition in Terrestial Ecosystems. Annu. Rev. Ecol. Evol. Syst. 2005, 36, 191-218. [CrossRef]

11. Van der Heijden, M.G.A.; Kilronomos, J.N.; Ursic, M.; Moutoglis, P.; Streitwolf-Engel, R.; Boller, T.; Wiemken, A.; Sanders, I.R. Mycorrhizal Fungal Diversity Determines Plant Biodiversity, Ecosystem Variability and Productivity. Nature 1998, 396, 69-72. [CrossRef]

12. Bonet, J.A.; González-olabarria, J.R.; Martínez-de-Aragón, J. Mushroom Production as an Alternative for Rural Development in a Forested Mountainous Area. J. Mt. Sci. 2014, 11, 535-543. [CrossRef]

13. Büntgen, U.; Latorre, J.; Egli, S.; Martínez-Peña, F. Socio-Economic, Scientific, and Political Benefits of Mycotourism. Ecosphere 2017, 8, e01870. [CrossRef]

14. Pausas, J.G.; Llovet, J.; Anselm, R.; Vallejo, R. Are Wildfires a Disaster in the Mediterranean Basin?-A Review Vegetation Changes Shrublands Dominated by Resprouting Species. Int. J. Wildl. Fire 2008, 17, 713-723. [CrossRef]

15. Wallenius, T.H.; Kauhanen, H.; Herva, H.; Pennanen, J. Long Fire Cycle in Northern Boreal Pinus Forests in Finnish Lapland. Can. J. For. Res. 2010, 40, 2027-2035. [CrossRef]

16. Fernandes, P.M.; Vega, J.A.; Jiménez, E.; Rigolot, E. Fire Resistance of European Pines. For. Ecol. Manag. 2008, 256, 246-255. [CrossRef]

17. Angelsam, P.; Kuuluvainen, T. Boreal Forest Disturbance Regimes, Successional Dynamics and Landscape Structures: A European Perspective. Ecol. Bull. 2004, 51, 117-136.

18. Vernet, J.-L. History of the Pinus Sylvestris and Pinus Nigra Ssp. Salzmanni Forest in the Sub-Mediterranean Mountains (Grands Causses, Pinus Saint-Guilhem-Le-Désert, Southern Massif Central, France) Based on Charcoal from Limestone and Dolomitic Deposits. Veg. Hist. Archaeobot. 2006, 16, 23-42. [CrossRef]

19. Pimont, F.; Prodon, R.; Rigolot, E. Comparison of Postfire Mortality in Endemic Corsican Black Pine (Pinus Nigra Ssp. Laricio) and Its Direct Competitor (Pinus Pinaster). Ann. For. Sci. 2011, 68, 425-432. [CrossRef]

20. Peay, K.G.; Garbelotto, M.; Bruns, T.D. Spore Heat Resistance Plays an Important Role in DisturbanceMediated Assemblage Shift of Ectomycorrhizal Fungi Colonizing Pinus Muricata Seedlings. J. Ecol. 2009, 97, 537-547. [CrossRef] 
21. Dahlberg, A.; Schimmel, J.; Taylor, A.F.S.; Johannesson, H. Post-fire Legacy of Ectomycorrhizal Fungal Communities in the Swedish Boreal Forest in Relation to fire Severity and Logging Intensity. 2001, 100, 151-161. [CrossRef]

22. Kropp, B.R.; Albee, S. The effects of silvicultural treatments on ocurrence of mycorrhizal sporocarps in a Pinus contorta forest: A preliminary study. Biol. Conserv. 1996, 70, 313-318. [CrossRef]

23. Martínez de Aragón, J.; Bonet, J.A.; Fischer, C.R.; Colinas, C. Productivity of Ectomycorrhizal and Selected Edible Saprotrophic Fungi in Pine Forests of the Pre-Pyrenees Mountains, Spain: Predictive Equations for Forest Management of Mycological Resources. For. Ecol. Manag. 2007, 252, 239-256. [CrossRef]

24. Cairney, J.W.G.; Bastias, B.A. Influences of Fire on Forest Soil Fungal Communities. Can. J. For. Res. 2007, 37, 207-215. [CrossRef]

25. Gassibe, P.V.; Fabero, R.F.; Hernández-Rodríguez, M.; Oria-de-Rueda, J.A.; Martín-Pinto, P. Fungal Community Succession Following Wildfire in a Mediterranean Vegetation Type Dominated by Pinus Pinaster in Northwest Spain. For. Ecol. Manag. 2011, 262, 655-662. [CrossRef]

26. Mediavilla, O.; Oria-de-Rueda, J.A.; Martín-Pinto, P. Changes in Sporocarp Production and Vegetation Following Wildfire in a Mediterranean Forest Ecosystem Dominated by Pinus Nigra in Northern Spain. For. Ecol. Manag. 2014, 331, 85-92. [CrossRef]

27. Gassibe, P.V.; Fabero, R.F.; Hernández-Rodríguez, M.; Oria-de-Rueda, J.A.; Oviedo, F.B.; Martín-Pinto, P. Post-Fire Production of Mushrooms in Pinus Pinaster Forests Using Classificatory Models. J. For. Res. 2014, 19, 348-356. [CrossRef]

28. Claridge, A.W.; Trappe, J.M.; Hansen, K. Do Fungi Have a Role as Soil Stabilizers and Remediators after Forest Fire? For. Ecol. Manag. 2009, 257, 1063-1069. [CrossRef]

29. Lindahl, B.O.; Taylor, F.S.; Finlay, R.D. Defining Nutritunial Constraints on Carbon Cycling in Boreal Forests-towards a Less "Phytocentric" Perspective. Plant Soil 2002, 242, 123-135. [CrossRef]

30. Motiejunaite, J.; Adamonyte, G.; Iršenaite, R.; Juzenas, S.; Kasparavičius, J.; Kutorga, E.; Markovskaja, S. Early Fungal Community Succession Following Crown Fire in Pinus Mugo Stands and Surface Fire in Pinus Sylvestris Stands. Eur. J. For. Res. 2014, 133, 745-756. [CrossRef]

31. Liu, Y.; Goodrick, S.L.; Stanturf, J.A. Future U.S. Wildfire Potential Trends Projected Using a Dynamically Downscaled Climate Change Scenario. For. Ecol. Manag. 2013, 294, 120-135. [CrossRef]

32. Salo, K.; Kouki, J. Severity of Forest Wildfire Had a Major Influence on Early Successional Ectomycorrhizal Macrofungi Assemblages, Including Edible Mushrooms. For. Ecol. Manag. 2018, 415-416, 70-84. [CrossRef]

33. Rincón, A.; Pueyo, J.J. Effect of Fire Severity and Site Slope on Diversity and Structure of the Ectomycorrhizal Fungal Community Associated with Post-Fire Regenerated Pinus Pinaster Ait. Seedlings. For. Ecol. Manag. 2010, 260, 361-369. [CrossRef]

34. Bonet, J.A.; Fischer, C.R.; Colinas, C. The Relationship between Forest Age and Aspect on the Production of Sporocarps of Ectomycorrhizal Fungi in Pinus Sylvestris Forests of the Central Pyrenees. For. Ecol. Manag. 2004, 203, 157-175. [CrossRef]

35. Martín-Pinto, P.; Vaquerizo, H.; Peñalver, F.; Olaizola, J.; Oria-De-Rueda, J.A. Early Effects of a Wildfire on the Diversity and Production of Fungal Communities in Mediterranean Vegetation Types Dominated by Cistus Ladanifer and Pinus Pinaster in Spain. For. Ecol. Manag. 2006, 225, 296-305. [CrossRef]

36. Knudsen, H.; Vesterholt, J. Funga Nordica: Agaricoid, Boletoid and Cyphelloid Genera; Nordsvamp: Copenhagen, Denmark, 2008.

37. Von Bonsdorff, T.; Hopsu-Neuvonen, A.; Huhtinen, S.; Korhonen, J.; Kosonen, L.; Moisio, S.; Palmén, J. Sienimetsästä markkinoille; Opetushallitus: Helsinki, Finland, 2013.

38. Ter Braak, C.J.F.; Prentice, I.C. A Theory of Gradient Analysis. Adv. Ecol. Res. 2013, 34, 271-317.

39. Ter Braak, C.J.F.; Šmilauer, P. CANOCO Reference Manual and CanoDraw for Windows User's Guide: Software for Canonical Community Ordination (Version 4.5); Microcomputer Power: Ithaca, NY, USA, 2002.

40. Oria-de-Rueda, J.A.; Hernández-Rodriguez, M.; Martín-Pinto, P.; Pando, V.; Olaizola, J. Could Artificial Reforestations Provide as Much Production and Diversity of Fungal Species as Natural Forest Stands in Marginal Mediterranean Areas? For. Ecol. Manag. 2010, 260, 171-180. [CrossRef]

41. Dejene, T.; Oria-de-Rueda, J.A.; Martín-Pinto, P. Fungal Diversity and Succession Following Stand Development in Pinus Patula Schiede Ex Schltdl. \& Cham. Plantations in Ethiopia. For. Ecol. Manag. 2017, 395, 9-18. 
42. Buscardo, E.; Rodríguez-Echeverría, S.; De Angelis, P.; Freitas, H. Ectomycorrhizal Communities in Fire Prone Environments: Essential Partners for Pinetrees Re-Establishment. Ecosistemas 2009, 18, 55-63.

43. Sun, H.; Santalahti, M.; Pumpanen, J.; Köster, K.; Berninger, F.; Raffaello, T.; Jumpponen, A.; Asiegbu, F.O.; Heinonsalo, J. Fungal Community Shifts in Structure and Function across a Boreal Forest Fire Chronosequence. Appl. Environ. Microbiol. 2015, 81, 7869-7880. [CrossRef] [PubMed]

44. Castaño, C.; Lindahl, B.D.; Alday, J.G.; Hagenbo, A.; Martínez-de-Aragón, J.; Parladé, J.; Pera, J.; Bonet, J.A. Soil Microclimate Changes Affect Soil Fungal Communities in a Mediterranean Pine Forest. New Phytol. 2018, 220, 1211-1221. [CrossRef] [PubMed]

45. Dahlberg, A. Effects of Fire on Ectomycorrhizal Fungi in Fennoscandian Boreal Forests. Silva Fenn. 2002, 36, 69-80. [CrossRef]

46. Treseder, K.; Mack, M.C.; Cross, A. Relationships among Fires, Fungi, and Soil Dynamics in Alaskan Boreal Forests. Ecol. Appl. 2004, 14, 1826-1838. [CrossRef]

47. Dejene, T.; Oria-de-Rueda, J.A.; Martín-Pinto, P. Fungal Community Succession and Sporocarp Production Following Fire Occurrence in Dry Afromontane Forests of Ethiopia. For. Ecol. Manag. 2017, 398, 37-47. [CrossRef]

48. Visser, S. Ectomycorrhizal Fungal Succession in Jack Pine Stands Following Wildfire. New Phytol. 1995, 129, 389-401. [CrossRef]

49. Buscardo, E.; Freitas, H.; Pereira, J.S.; de Angelis, P. Common Environmental Factors Explain Both Ectomycorrhizal Species Diversity and Pine Regeneration Variability in a Post-Fire Mediterranean Forest. Mycorrhiza 2011, 21, 549-558. [CrossRef] [PubMed]

50. Baar, J.; Horton, T.; Kretzer, A.; Bruns, T. Mycorrhizal Colonization of Pinus Muricata from Resistant Propagules after a Stand-replacing Wildfire. Aquat. Ecol. 1999, 143, 409-418.

51. Hernández-Rodríguez, M.; Oria-de-Rueda, J.A.; Martín-Pinto, P. Post-Fire Fungal Succession in a Mediterranean Ecosystem Dominated by Cistus Ladanifer L. For. Ecol. Manag. 2013, 289, 48-57. [CrossRef]

52. Ortega-Martínez, P.; Águeda, B.; Fernández-Toirán, L.M.; Martínez-Peña, F. Tree Age Influences on the Development of Edible Ectomycorrhizal Fungi Sporocarps in Pinus Sylvestris Stands. Mycorrhiza 2011, 21, 65-70. [CrossRef]

53. Jonsson, L.M.; Nilsson, M.C.; Wardle, D.A.; Zackrisson, O. Context Dependent Effects of Ectomycorrhizal Species Richness on Tree Seedling Productivity. Oikos 2001, 93, 353-364. [CrossRef]

54. Baxter, J.W.; Dighton, J. Phosphorus Source Alters Host Plant Response to Ectomycorrhizal Diversity. Mycorrhiza 2005, 15, 513-523. [CrossRef] [PubMed]

55. Buée, M.; Courty, P.E.; Mignot, D.; Garbaye, J. Soil Niche Effect on Species Diversity and Catabolic Activities in an Ectomycorrhizal Fungal Community. Soil Biol. Biochem. 2007, 39, 1947-1955. [CrossRef]

56. Oliver, A.K.; Callaham, M.A.; Jumpponen, A. Soil Fungal Communities Respond Compositionally to Recurring Frequent Prescribed Burning in a Managed Southeastern US Forest Ecosystem. For. Ecol. Manag. 2015, 345, 1-9. [CrossRef]

57. Fujimura, K.E.; Smith, J.E.; Horton, T.R.; Weber, N.S.; Spatafora, J.W. Pezizalean Mycorrhizas and Sporocarps in Ponderosa Pine (Pinus Ponderosa) after Prescribed Fires in Eastern Oregon, USA. Mycorrhiza 2005, 15, 79-86. [CrossRef]

58. Agerer, R. Exploration Types of Ectomycorrhizae: A Proposal to Classify Ectomycorrhizal Mycelial Systems According to Their Patterns of Differentiation and Putative Ecological Importance. Mycorrhiza 2001, 11, 107-114. [CrossRef]

59. Torres, P.; Honrubia, M. Changes and Effects of a Natural Fire on Ectomycorrhizal Inoculum Potential of Soil in a Pinus Halepensis Forest. For. Ecol. Manag. 1997, 96, 189-196. [CrossRef]

60. Santos-Silva, C.; Louro, R. Assessment of the Diversity of Epigeous Basidiomycota under Different Soil-Management Systems in a Montado Ecosystem: A Case Study Conducted in Alentejo. Agrofor. Syst. 2016, 90, 117-126. [CrossRef]

(c) 2019 by the authors. Licensee MDPI, Basel, Switzerland. This article is an open access article distributed under the terms and conditions of the Creative Commons Attribution (CC BY) license (http:/ / creativecommons.org/licenses/by/4.0/). 